\title{
FULL LENGTH RESEARCH ARTICLE \\ COMPARATIVE STUDY OF BIODEGRADATION OF CRUDE OIL IN SOIL AMENDED WITH CHICKEN DROPPINGS AND NPK FERTILIZER
}

\author{
*IJAH U. J. J.; SAFIYANU, H. \& ABIOYE, O. P. \\ Department of Microbiology \\ Federal University of Technology \\ P.M.B. 65, Minna, Nigeria \\ *(Corresponding author) \\ udemijah@yahoo.com
}

\begin{abstract}
Analysis of soil samples treated with 10\% (v/w) Escravos light crude oil and amended with chicken droppings and NPK fertilizer revealed that the aerobic heterotrophic bacterial counts were depressed while the proliferation of crude oil degrading bacteria (CDB) in the soil was encouraged. The counts of CDB in oil free (control) soil ranged from $20 \times 10^{8} \mathrm{CFU} / \mathrm{g}$ to $33 \times 10^{8} \mathrm{CFU} / \mathrm{g}$ of soil, while that of oil polluted soil ranged from $48 \times 10^{8} \mathrm{CFU} / \mathrm{g}$ to $93 \times 10^{8} \mathrm{CFU} / \mathrm{g}$ soil after $10 \mathrm{wks}$. In fertilizer amended soil, the counts of CDB ranged from $40 \times 10^{8} \mathrm{CFU} / \mathrm{g}$ to $92 \times 10^{8} \mathrm{CFU} / \mathrm{g}$ of soil and from $53 \times 10^{8} \mathrm{CFU} / \mathrm{g}$ to $95 \times 10^{8} \mathrm{CFU} / \mathrm{g}$ in soil amended with chicken droppings. The crude oil degrading bacteria were identified as species of Bacillus, Pseudomonas, Acinetobacter and Micrococcus. The isolate Bacillus sp. SOB-10 exhibited a high ability in degrading the crude oil. The organism degraded $54.6 \%$ of crude oil in 14 days and therefore, may be useful in seeding oil-polluted soil. Crude oil addition to soil raised the $\mathrm{pH}$ from 6.75 to 7.65 and amendment of the oil-polluted soil with chicken droppings further raised the soil pH (7.17 - 7.76). Amendment of the oil polluted soil with fertilizer however, caused a remarkable decrease in the soil pH (5.91 6.26). Biodegradation studies revealed that $56.3 \%$ of crude oil was degraded in the unamended soil while $75 \%$ and $87.5 \%$ of crude oil was degraded in soil amended with chicken droppings and fertilizer respectively after 10 wks. This indicates that chicken droppings and NPK fertilizer enhanced the biodegradation process.
\end{abstract}

Key words: Amendment, biodegradation, crude oil, soil.

\section{INTRODUCTION}

The biodegradation of crude oil in the natural environment is a slow process. The major factor responsible for this is the nutritional imbalance created by oil spills. Therefore, addition of nutrients (in the form of inorganic fertilizer) coupled with physicochemical processes and microbial seeding has been found to be effective in dealing with oil spills in soil (Ismailov 1985; Bartha 1986; ljah \& George 1998; ljah \& Ndana 2003; Adenipekun \& Fasidi 2005; Iquatt et al. 2006). The added fertilizer provides nitrogen and phosphorus to the crude oil degrading microorganisms in the soil, thereby promoting the growth and crude oil degrading capability of the organisms.

Unfortunately, the use of fertilizer in treating oil spills may be expensive. Therefore, a cheap alternative like chicken droppings has been suggested (ljah \& Antai 2003a). Chicken droppings contain nitrogen and phosphorus (Adeleye 1991), which are necessary for crude oil degradation. In addition, chicken droppings harbour bacteria and fungi that can utilize crude oil efficiently (ljah \& Antai 2003a). The aim of the present study is to assess the effectiveness of chicken droppings in enhancing crude oil biodegradation in soil in comparison to the use of inorganic fertilizer.

\section{MATERIALS AND METHODS}

Collection and processing of samples: The crude oil type used was Escravos light crude with specific gravity of 0.8467 . Soil was collected from farmlands near the Nigerian National Petroleum Corporation (NNPC) Fuel Depot, Minna, Nigeria. Surface soil $(0-20 \mathrm{~cm})$ was collected and bulked to form a composite sample, which was transferred to the laboratory, air - dried and sieved through a $2 \mathrm{~mm}$ mesh before use. Chicken droppings were collected fresh from caged lavers in Niqer Livestock Companv Limited Minna and sun - dried for 48h, ground and stored in polythene bags in the laboratory until required. The microbiological and physicochemical qualities of chicken droppings have been described (ljah \& Antai 2003a). The NPK fertilizer used was collected from Nigerian Agricultural Development Project (NADP), Minna, Nigeria.

Measurement of crude oil biodegradation in soil amended with NPK fertilizer and chicken droppings: $300 \mathrm{~g}$ of soil was added to each plastic container (PC) and the following treatments were carried out: PC1 had 10\% (v/w) crude oil; PC2 had 10\% crude oil plus $50 \mathrm{~g}$ NPK fertilizer; PC3 had $10 \%$ crude oil plus $50 \mathrm{~g}$ of chicken droppings. PC4 had no crude oil added and served as a control. The experiment, which was set up in duplicates was incubated at room temperature (28 $\pm 2^{\circ} \mathrm{C}$ ). After every two weeks, the soil samples were analyzed for crude oil loss, $\mathrm{pH}$ and microbial counts throughout the 10 wks duration of the study as follows:

Crude oil loss (biodegradation): The rates and total extent of crude oil biodegradation in soil were determined by suspending $10 \mathrm{~g}$ of soil in $5 \mathrm{ml}$ of diethyl ether in a $250 \mathrm{ml}$ capacity Erlenmeyer flask. The flask was shaken vigorously to extract the oil. This was repeated until all the oil was extracted from the soil. The solvent - oil mixture was transferred slowly into a beaker of known weight and the solvent allowed to evaporate completely. The new weight of the beaker (now containing residual oil) was recorded. Percentage biodegradation of crude oil was calculated (ljah \& Ukpe 1992).

pH determination: $\mathrm{pH}$ of the soil was determined with the $\mathrm{pH}$ meter (Micro pH 2000 Crison Instrument, S.A., Barcelona) on 1:2.5 (w/v) soil/water mixture, after $30 \mathrm{~min}$ equilibration. Duplicate determinations were made. 
Microbial counts: Microorganisms in the oil-polluted soil were enumerated by spread inoculating $0.1 \mathrm{ml}$ of serially diluted sample onto nutrient agar (NA) plates for the enumeration of aerobic heterotrophic bacteria. Crude oil degrading bacteria were enumerated on oil agar, $\mathrm{OA}\left(1.2 \mathrm{~g} \mathrm{KH}_{2} \mathrm{PO}_{4}, 1.8 \mathrm{~g} \mathrm{~K}_{2} \mathrm{HPO}_{4} 4.0 \mathrm{~g} \mathrm{NH}_{4} \mathrm{Cl}, 0.2 \mathrm{~g} \mathrm{MgSO}_{4} .7 \mathrm{H}_{2} \mathrm{O}, 0.1 \mathrm{~g}\right.$ $\mathrm{NaCl}, 0.01 \mathrm{~g} \mathrm{FeSO}_{4} .7 \mathrm{H}_{2} \mathrm{O}, 20 \mathrm{~g}$ agar, $0.5 \%$ crude oil in $1000 \mathrm{ml}$ of distilled water, $\mathrm{pH}$ 7.4). The inoculated NA and OA plates were incubated at $30^{\circ} \mathrm{C}$ for $48 \mathrm{~h}$ and $72 \mathrm{~h}$ respectively. Colonies, which appeared on the plates, were counted and expressed as colony forming units per gramme of soil $(\mathrm{CFU} / \mathrm{g})$. The organisms were isolated and maintained on agar slants for further identification.

Characterization and identification of microbial isolates: The bacterial isolates were characterized based on their cultural and biochemical properties including the ability of the organisms to utilize various carbohydrates (glucose, inositol, xylose, mannitol, sucrose, raffinose and maltose). The identities of the bacterial isolates were confirmed by comparing their characteristics with those of known taxa as outlined in Bergey's Manual of Systematic Bacteriology (Krieg \& Holt 1994).
Utilization of crude oil by bacterial isolates: The bacterial isolates were tested for ability to grow on and utilize crude oil as sole carbon source using solid (OA) and liquid media with added crude oil. The OA and liquid medium were inoculated with the isolates and incubated at $30^{\circ} \mathrm{C}$ for 5 days and 14 days respectively. At the end of the incubation period, bacterial growth on the OA was recorded while the extent of oil utilization in the liquid medium was determined by the weight loss method of Bossert \& Bartha (1984).

\section{RESULTS}

The results revealed that the rates of crude oil biodegradation gradually increased with time and reached $56.3 \%$ after 10 wks in unamended soil. In soil amended with chicken droppings, the total extent of oil biodegradation was $75 \%$ after 10 wks whereas $87.5 \%$ of the oil was degraded in soil amended with NPK fertilizer over the same period (Fig 1).

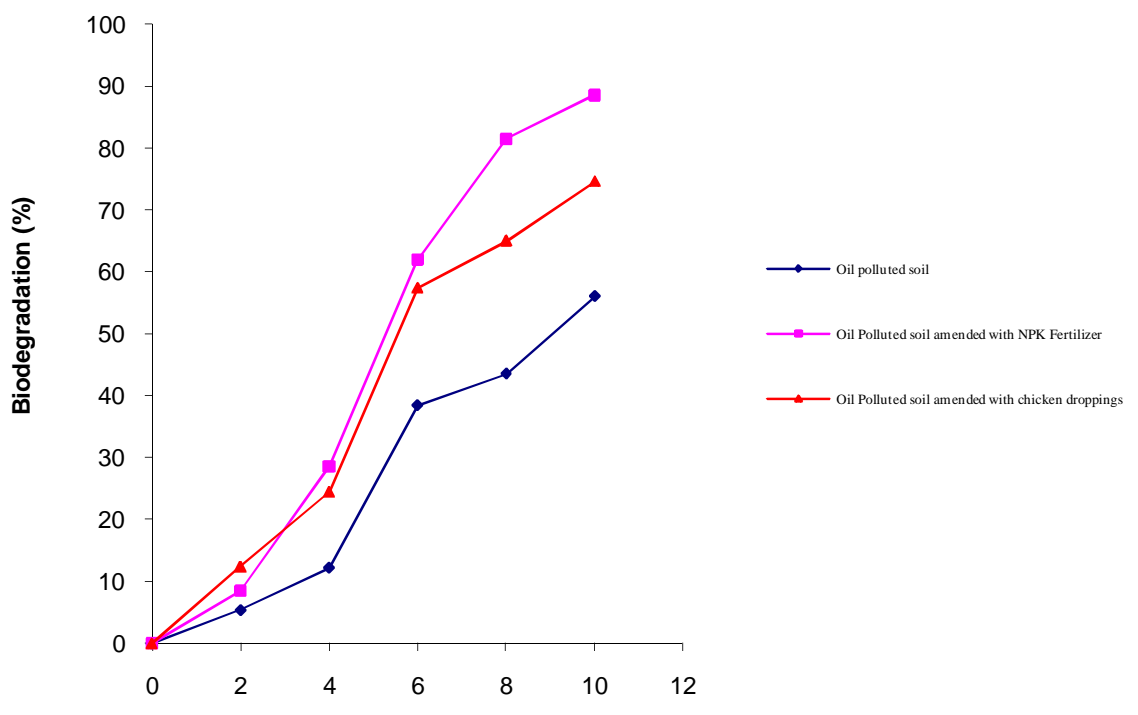

FIG. 1. BIODEGRADATION OF CRUDE OIL IN SOIL

The $\mathrm{pH}$ of the oil free soil ranged from $6.40-7.19$ while that of the oil polluted soil ranged from 6.75-7.69 (Fig. 2).

The aerobic heterotropic bacterial counts in oil free (control) soil ranged from $4.5 \times 10^{10} \mathrm{CFU} / \mathrm{g}$ to $37 \times 10^{10} \mathrm{CFU} / \mathrm{g}$ of soil while the counts in oil polluted soil ranged from $7.2 \times 10^{10} \mathrm{CFU} / \mathrm{g}$ to $49 \times 10^{10} \mathrm{CFU} / \mathrm{g}$ (Fig. 3)

The counts (Fig. 4) of crude oil utilizing bacteria in the oil polluted soil $\left(48 \times 10^{8} \mathrm{CFU} / \mathrm{g}-93 \times 10^{8} \mathrm{CFU} / \mathrm{g}\right)$ were higher than that of the oil free soil $\left(20 \times 10^{8} \mathrm{CFU} / \mathrm{g}-33 \times 10^{8} \mathrm{CFU} / \mathrm{g}\right)$. The crude oil utilizing bacteria were identified as belonging to the genera Bacillus, Pseudomonas, Acinetobacter and Micrococcus. The organisms degraded the crude oil to varying degrees (Table 1). Bacillus sp. SOB-06 exhibited a considerable high growth on oil agar and degraded $54.6 \%$ crude oil after 14 days as compared to $28.5 \%-45.8 \%$ crude oil degradation caused by other isolates over the same period (Table 1 ).

\section{DISCUSSION}

The results show that more crude oil biodegradation has occurred in amended soil than in unamended control soil, meaning that chicken droppings and NPK fertilizer are enhancers of crude oil biodegradation in the soil. Enhanced crude oil biodegradation in soil using organic manure or chemical fertilizer has been reported elsewhere (Sandvik et al. 1986; El-Nawawy et al. 1992; ljah \& Antai 2003a; Philp \& Atlas 2005; Ubochi et al. 2006; Abu \& Onisuru 2006). The enhancement may be due to nutrients (nitrogen and phosphorus) present in the chicken droppings and fertilizer. In addition, the crude oil degrading microorganisms in chicken droppings may have participated in the oil 


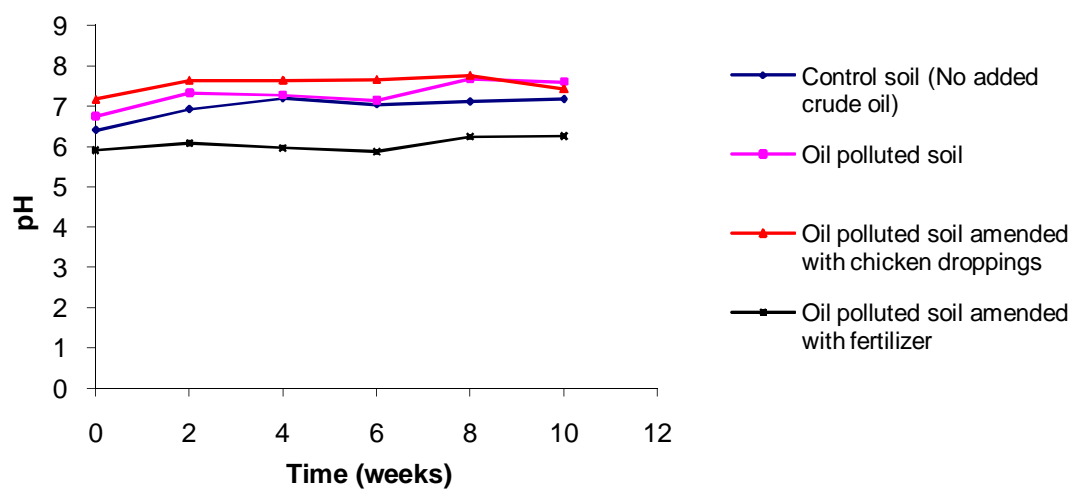

FIG. 2. PH OF OIL POLLUTED SOIL

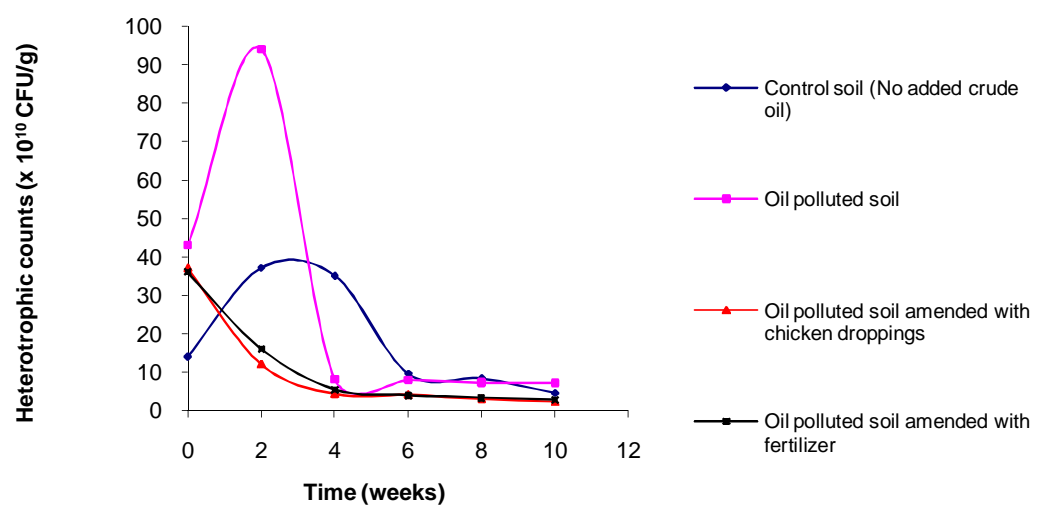

FIG. 3. TOTAL AEROBIC HETEROTROPHIC BACTERIAL COUNTS IN OIL-POLLUTED SOIL

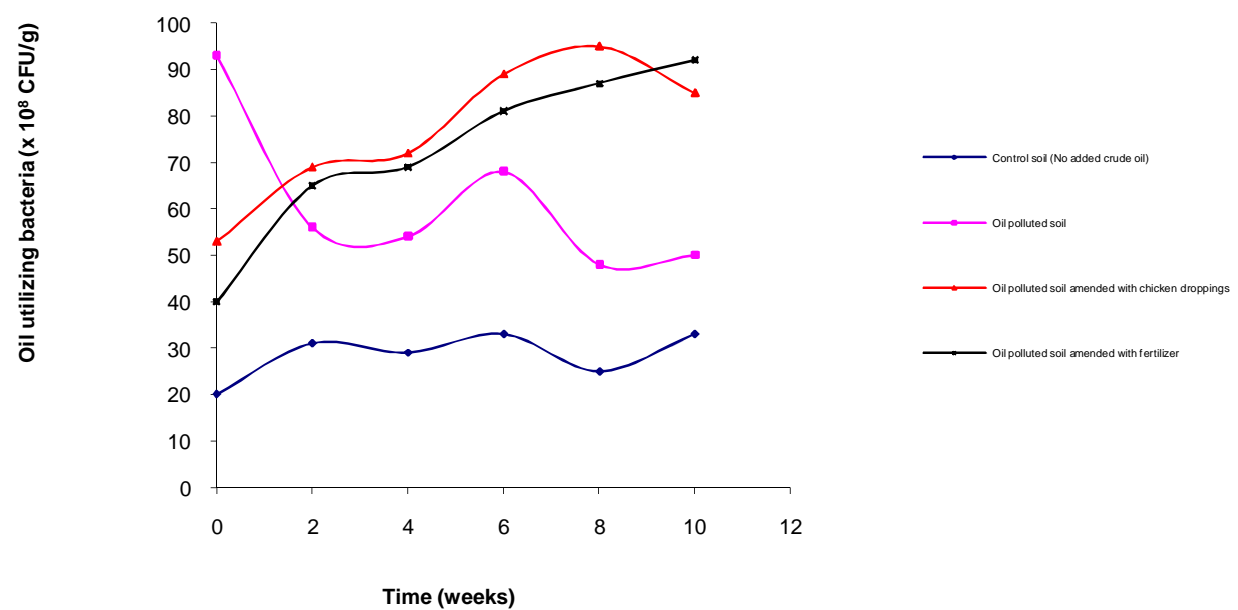

FIG. 4. COUNTS OF CRUDE OIL UTILIZING BACTERIA IN OIL POLLUTED SOIL 
TABLE 1: GROWTH AND EXTENT OF CRUDE OIL DEGRADATION BY BACTERIA

\begin{tabular}{lll}
\hline $\begin{array}{l}\text { Coded bacteria of } \\
\text { crude oil (\%) }\end{array}$ & $\begin{array}{l}\text { Growth on crude } \\
\text { oil agar }\end{array}$ & $\begin{array}{l}\text { Weight } \\
\text { loss }\end{array}$ \\
\hline Bacillus spp SOB-06 & +++ & 54.6 \\
Micrococcus sp SOB-13 & ++ & 45.8 \\
Pseudomonas sp SOB-09 & ++ & 42.7 \\
Bacillus sp SOB-14 & + & 38.2 \\
Bacillus sp SOB-01 & + & 32.9 \\
Acinetobacter sp SOB-03 & + & 28.5 \\
\hline +++:Heavy growth; ++:Moderate growth; +:Minimal growth
\end{tabular}

The $\mathrm{pH}$ of the oil free soil ranged from 6.40-7.19 while that of the oil polluted soil ranged from 6.75-7.69 (Fig. 2).

The aerobic heterotropic bacterial counts in oil free (control) soil ranged from $4.5 \times 10^{10} \mathrm{CFU} / \mathrm{g}$ to $37 \times 10^{10} \mathrm{CFU} / \mathrm{g}$ of soil while the counts in oil polluted soil ranged from $7.2 \times 10^{10} \mathrm{CFU} / \mathrm{g}$ to $49 \times 10^{10} \mathrm{CFU} / \mathrm{g}$ (Fig. 3)

The counts (Fig. 4) of crude oil utilizing bacteria in the oil polluted soil $\left(48 \times 10^{8} \mathrm{CFU} / \mathrm{g}-93 \times 10^{8} \mathrm{CFU} / \mathrm{g}\right.$ ) were higher than that of the oil free soil $\left(20 \times 10^{8} \mathrm{CFU} / \mathrm{g}-33 \times 10^{8} \mathrm{CFU} / \mathrm{g}\right)$. The crude oil utilizing bacteria were identified as belonging to the genera Bacillus, Pseudomonas, Acinetobacter and Micrococcus. The organisms degraded the crude oil to varying degrees (Table 1). Bacillus sp. SOB-06 exhibited a considerable high growth on oil agar and degraded $54.6 \%$ crude oil after 14 days as compared to $28.5 \%$ - $45.8 \%$ crude oil degradation caused by other isolates over the same period (Table 1).

breakdown process (ljah \& Antai 2003a). However, the total extent of oil biodegradation was slightly higher in soil amended with fertilizer than in soil amended with chicken droppings (Fig. 1). This may be due to the fact that nutrients were more abundant in fertilizer-amended soil than in soil amended with chicken droppings. It is also possible that nutrients were less tied up in fertilizer than in chicken droppings.

The results show that the addition of crude oil to soil raised the soil $\mathrm{pH}$ slightly. The pH of the oil polluted soil amended with NPK fertilizer was on the acidic range (5.87-6.26) while that of soil amended with chicken droppings ranged from 7.17-7.76 (Fig. 2). The results indicate that the chicken droppings may have advantage over NPK fertilizer in this aspect since the slightly alkaline nature of the soil will encourage the growth of crude oil degrading bacteria, and promote biodegradation of the oil. The results obtained confirm an earlier finding (ljah \& Antai 2003a) that chicken droppings have buffering effect on the soil. The fact that addition of fertilizer depressed the soil $\mathrm{pH}$ to the acidic side stresses the need of liming the soil.

The results also show that aerobic heterotropic bacterial counts were higher in oil-polluted soil than the oil free soil, a finding that agrees with the report of Pinholt (1979). Amendment of the oil polluted soil with either chicken droppings or NPK fertilizer caused a decrease in the counts of aerobic heterotrophic bacteria (Fig. 3). The decrease may be due to inhibitory effects of the components of chicken droppings or fertilizer on soil bacteria. This finding is however, contrary to the report of EL-Nawawy et al. (1992) that, combining oily sludge with the application of inorganic fertilizer gave higher numbers of aerobic bacteria months after application compared with untreated soil. One reason for the higher bacterial counts in oil-polluted soil than the oil-free soil was probably because the oil served as a source of carbon and energy to the organisms and therefore, encouraged their proliferation. Amendment of the oil polluted soil with chicken droppings and fertilizer stimulated more microbial proliferation in the soil. This may be due to nutrients (nitrogen and phosphorus) contained in the compounds. This finding agrees with the report of Atlas and Bartha (1992) that the amendment of oil polluted soil with fertilizer stimulated the proliferation of oil utilizing bacteria.

The crude utilizing bacteria identified in this study have been isolated and implicated in crude oil biodegradation by several investigators (Bossert \& Bartha 1984; Antai 1990; ljah 1998; ljah \& Antai 2003b; Ekpo \& Ekpo 2006; Ajayi et al. 2008). The high ability of Bacillus species isolated from Nigerian soil in degrading crude oil has consistently been observed (Antai \& Mgbomo 1989; Antai 1990; ljah \& Ukpe 1992; ljah 1998) and attributed to competent hydrocarbon degrading enzyme system of the organism, its ability to form spores and emulsify crude oil. Consequently, Bacillus sp SOB-06 may be useful in seeding oil polluted soil.

In conclusion, oil pollution of soil proved to alter soil pH, depress aerobic heterotrophic bacterial counts and encourage the proliferation of crude oil utilizing bacteria in the soil. Amendment of crude oil polluted soil with chicken droppings and NPK fertilizer caused more proliferation of crude oil degrading bacteria and enhanced microbial degradation of crude oil in the soil. NPK fertilizer caused more enhancement of the crude oil biodegradation than chicken droppings, although chicken droppings raised the $\mathrm{pH}$ of the soil to a level more favourable for the growth of crude oil degrading bacteria. In this investigation, species of Bacillus, Acinetobacter, Pseudomonas and Micrococcus participated in crude oil degradation in the soil but Bacillus sp. SOB-06 exhibited a considerable high ability in degrading the crude oil. Therefore, the organism may be useful in treating oil spills in tropical soil. Chicken droppings and NPK fertilizer can also play an important role in integrated crude oil pollution control. 


\section{REFERENCES}

Abu, G. O. \& Onisuru, P. T. 2006. Slow-release nutrient delivery in bioremediation of an oil-polluted water body and sediments of a Niger Delta site. Nigerian Journal of Microbiology 20(3):1443-1452.

Ajayi, A. O.; Balogun, S. A. \& Adegbehingbe, F. 2008. Microorganisms in the crude oil producing areas of Ondo State, Nigeria. Research Essay 3(5):174-179.

Adeleye, I. O. A. 1991. Dried poultry droppings as a source of dietary nitrogen for sheep fed corn-cobs based diets. West African Journal of Biological and Applied Chemistry 36 (1):19-32.

Adenipekun, C. O. \& Fasida, I. O. 2005. Bioremediation of oil-polluted soil by Lentinus subnudus, a Nigerian white-rot fungus. African Journal of Biotechnology 4(8):796-798.

Antai, S. P. 1990. Biodegradation of Bonny light crude oil by Bacillus sp. and Pseudomonas sp. Waste Management 10:61-64.

Antai, S. P. \& Mgomo, E. 1989. Distribution of hydrocarbon utilizing bacteria in oil-spill areas. Microbios Letters 40: 137-143.

Atlas, R. M \& Bartha, R. 1992. Hydrocarbon biodegradation and oil spill bioremediation. Advances in Microbial Ecology 12: 287-338.

Bartha, R. 1986. Biotechnology of petroleum pollutant biodegradation. Microbial Ecology 12:155-172.

Bossert, I \& Bartha, R. 1984. The fate of petroleum in soil ecosystems. In: Petroleum Microbiology, Ed. R.M. Atlas; Macmillan Publishing Company, New York, pp. 435-473.

El-Nawawy, A. S.; El-Bagouri, I. H.; Abdal, M. \& Khalafawi, M. S. 1992. Biodegradation of oily sludge in Kuwait soil. World Journal of Microbiology and Biotechnology 8:618-620.

Ekpo, M. A. \& Ekpo, M. I. 2006. Utilization of Bonny light and Bonny medium crude oils by microorganisms isolated from Qua Iboe River estuary. Nigerian Journal of Microbiology 20(1):832-859.

ljah, U. J. J. 1998. Studies on relative capabilities of bacterial and yeast isolates from tropical soil in degrading crude oil. Waste Management 18:293-299.
Ijah, U. J. J. \& Antai, S. P. 2003a. The potential use of chicken-drop microorganism for oil spill remediation. The Environmentalist 23:89-95.

ljah, U. J. J. \& Antai, S. P. 2003b. Removal of Nigerian light crude oil in soil over a 12-month period. International Bioterioration and Biodegradation 51:93-99.

ljah, U J J; George, B. G. 1998. Potentials of yeast isolates in decontaminating crude oil spilled soil. Nigerian Journal of Science Technology 1(1):1-9.

ljah, U. J. J. \& Ndana, M. 2003. Stimulated biodegradation of crude oil in soil amended with periwinkle shells. The Environmentalist 23:249254.

ljah, U. J. J. \& Ukpe, L. I. 1992. Biodegradation of crude oil by Bacillus strains $28 \mathrm{~A}$ and $61 \mathrm{~B}$ isolated from oil spilled soil. Waste Management 12:55-60.

Iquatt, C. B.; Oyewole, O. A. \& Abioye, O. P. 2006. Bioremediation of petroleum polluted soil (a review). International Journal of Natural and Applied Sciences 1(1):21-25.

Ismailov, N. M. 1985. Biodegradation of oil hydrocarbons in soil inoculated with yeasts. Microbiology 54:670-675.

Krieg, N. R.; Holt, J. G eds. (1994). Bergey's Manual of Systematic Bacteriology. William and Wilkins Ltd., Baltimore.

Pinholt, Y., Struwe, S. \& Kjoller, A. 1979. Microbial changes during oil decomposition in soil. Holartic Ecology 2:195- 200

Sandvik, S.; Lode, A. \& Pederson, T. A. 1986. Biodegradation of oily sludge in Norwegian soil. Applied Microbiology and Biotechnology 23:297-301.

Ubochi, K. C.; Ibekwe, V. I. \& Ezeji, E. U. 2006. Effect of inorganic fertilizer on microbial utilization of hydrocarbons on oil contaminated soil. African Journal of Biotechnology 5(17):1584-1587. 